\title{
INTEGRASI BAHAN AJAR IPA MENGGUNAKAN MODEL ROBIN FOGARTY UNTUK PROSES PEMBELAJARAN IPA DI SMP
}

\section{THE INTEGRATION OF SCIENCE TEACHING MATERIALS BASED ROBIN FOGARTY MODEL FOR THE LEARNING SCIENCE PROCES IN JUNIOR HIGH SCHOOL}

\author{
Ghery Priscylio $^{1 *}$, Sjaeful Anwar $^{2}$ \\ ${ }^{1}$ Pendidikan IPA, Sekolah Pascasarjana Universitas Pendidikan Indonesia, Indonesia \\ ${ }^{2}$ Program Studi Pendidikan Kimia, FPMIPA Universitas Pendidikan Indonesia, Indonesia \\ *Email: ghery.priscylio@upi.edu
}

Diterima: 11 Desember 2018. Disetujui: 06 Februari 2019. Dipublikasikan: 31 Maret 2019

\begin{abstract}
Abstrak: Penelitian ini menyajikan tinjauan literatur tentang integrasi dari bahan ajar IPA menggunakan model Robin Fogarty yang dapat digunakan dalam pembelajaran IPA di SMP. Bahan ajar adalah segala bentuk bahan berupa seperangkat materi yang disusun secara sistematis yang digunakan untuk membantu guru dalam melaksanakan kegiatan pembelajaran dan kemungkinan siswa untuk belajar. Menurut Robin Fogarty terdapat 10 model pembelajaran terpadu yaitu model terpisah (fragmented), keterkaitan/keterhubungan (connected), berbentuk sarang (nested), dalam satu rangkaian (sequenced), terbagi (shared), bentuk jaring laba- laba (webbed), dalam satu alur (threaded), terpadu (integrated), tenggelam (immersed), membentuk jejaring (networked). Model pembelajaran terpadu dari Robin Fogarty ini diterapkan dalam pengembangan bahan ajar IPA. Penelitian pengembangan bahan ajar IPA menyertakan tipe keterpaduan yang digunakan. Ada banyak tema, metode pengembangan yang digunakan dalam pengembangan bahan ajar IPA. Ada juga yang mengembangkan bahan ajar IPA dalam satu topik saja. Dengan demikian dihasilkan bahan ajar IPA dengan berbagai macam model keterpaduan sehingga diharapkan dapat digunakan guru dalam pembelajaran IPA terpadu di SMP/ MTs.
\end{abstract}

Kata Kunci : Bahan Ajar IPA, Integrated Curriculum, Model Robin Fogarty, Pendidikan IPA

Abstract: This study presents a review of literature on the integration of science teaching materials using the Robin Fogarty model that can be integrated in science learning in junior high school. Teaching materials are all forms of material in the form of a systematic set of material that is used to assist teachers in carrying out learning activities. According to Robin Fogarty, there are 10 integrated learning models i.e fragmented, connected, nested, sequenced, shared, webbed, threaded, integrated, immersed, networked. This integrated learning model from Robin Fogarty is applied in the development of science teaching materials. Research on the development of science teaching materials includes the type of cohesiveness used. There are many development methods used in the development of science teaching materials. There are also only single topic developments as a science teaching materials. Thus science learning materials are produced with various types of cohesiveness so that it is expected that teachers can be used in integrated science learning in junior high school.

Keywords : Science Teaching Material, Integrated Curriculum, Robin Fogarty Models, Science Education

\section{PENDAHULUAN}

Pendidikan merupakan salah satu faktor penting bagi kemajuan suatu bangsa dan peningkatan sumber daya manusia (SDM). Oleh karena itu pendidikan di Indonesia selalu berubah menyesuaikan perkembangan zaman dan teknologi agar kualitas sumber daya manusia (SDM) Indonesia selalu meningkat dan lebih baik $[1,9,11,32,46]$. Semakin membaiknya kualitas pendidikan di Indonesia maka SDM Indonesia juga akan semakin berkualitas. Salah satu upaya pemerintah dalam meningkatkan kualitas pendidikan di Indonesia yaitu dengan penyempurnaan kurikulum pendidikan [10]. Kurikulum adalah perangkat yang berisi rancangan pelajaran dan cara yang digunakan sebagai pedoman penyelenggaraan kegiatan belajar mengajar yang akan diberikan kepada siswa dalam jangka waktu tertentu [41]. Kurikulum yang diterapkan pada pendidikan Indonesia saat ini adalah Kurikulum 2013. Kurikulum 2013 akan menjadi pedoman pelaksaan pembelajaran pada setiap mata pelajaran di tiap jenjang pendidikan, termasuk pada proses pembelajaran IPA terpadu di Sekolah Menengah Pertama (SMP).

Pembelajaran IPA terpadu merupakan salah satu model implementasi kurikulum yang dianjurkan untuk di aplikasikan pada jenjang SMP yaitu dengan menghubungkan kajian kimia, fisika dan biologi [2, 28, 31, 32, 40, 44]. Sehingga diperlukan suatu model keterpaduan untuk mengintegrasikan konten dan kemampuan ilmiah Sains, keterampilan praktis, sikap, dan nilai-nilai $\left[\begin{array}{lll}6, & 37\end{array}\right]$ serta 
mengkombinasikan materi kimia, fisika dan biologi dalam pembelajaran [34]. Dengan adanya integrasi ini diharapkan dapat meningkatkan kualitas pembelajaran, meningkatkan minat siswa, keterampilan berpikir kritis dan pembelajaran IPA menjadi lebih bermakna [7, 8]. Menurut Robin Fogarty terdapat 10 tipe pembelajaran terpadu yang dapat diterapkan dalam pembelajaran IPA yaitu model terpisah (fragmented), keterkaitan/keterhubungan (connected), berbentuk sarang (nested), dalam satu rangkaian (sequenced), terbagi (shared), bentuk jaring laba- laba (webbed), dalam satu alur (threaded), terpadu (integrated), tenggelam (immersed), membentuk jejaring (networked) [19, 21, 22].

Ilmu Pengetahuan Alam (IPA) merupakan ilmu pengetahuan yang mempelajari gejala-gejala di alam semesta, baik benda hidup maupun benda tak hidup, dengan menggunakan metode ilmiah dan menghasilkan teori-teori yang tersusun secara sistematis [35]. IPA merupakan suatu kesatuan pengetahuan yang utuh dan di dalamnya terdapat sejumlah materi atau konsep yang saling terkait satu sama lain dan bersifat menyeluruh [26, 38]. Namun, di sekolah saat ini IPA sering kali disajikan sebagai kumpulan - kumpulan fakta dan konsep tanpa menghubungkan keterkaitan antar fakta dari ketiga sudut pandang keilmuan IPA [14]. Pembelajaran IPA terpadu masih sulit untuk dilaksanakan. Guru memiliki kesulitan dalam membuat RPP, media, bahan ajar yang akan digunakan dalam setiap model keterpaduan dan memadukan konsep kimia, fisika, biologi dalam satu pokok bahasan yang sedang diajarkan [29]. Kesulitan ini muncul karena kurangnya pemahaman konsep guru $[4,36]$. Hal ini disebabkan oleh latar belakang pendidikan guru IPA saat ini kebanyakan berasal dari kimia, fisika, biologi dan teknik. Sedangkan mereka diminta untuk mengajarkan konsep IPA terpadu yang merupakan gabungan dari kimia, fisika dan biologi [43]. Maka pada pelaksanaan pembelajaran terpadu dituntut profesionalitas guru dalam mengajar dan kerja sama yang baik antar guru IPA pada ada di suatu sekolah agar saling melengkapi pengetahuan konsep satu sama lain dari masing-masing latar belakang pendidikan [17, 31]. Salah satu faktor yang dapat membantu guru dalam mengajarkan IPA terpadu adalah tersedianya bahan ajar IPA terpadu [25].

Bahan ajar merupakan salah satu aspek penting yang berisi pengetahuan, konsep, fakta, materi yang nyata, baik yang dicetak maupun yang belum digunakan yang digunakan sebagai sumber bahan belajar [49]. Bahan ajar IPA terpadu juga perlu memperhatikan tipe keterpaduan Robin Fogarty agar dapat digunakan untuk mendukung pembelajaran IPA terpadu sesuai dengan tipe keterpaduan yang diterapkan oleh guru dalam pembelajaran. Setiap tipe keterpaduan dari Robin Fogarty memiliki karakteristik yang berbeda- beda sehingga jika diadopsi kedalam suatu bahan ajar tentu akan memberikan karakteristik tersendiri pada bahan ajar tersebut. Berbeda tipe keterpaduan yang diterapkan maka bahan ajar yang dihasilkan juga akan berbeda. Pada artikel ini, kami akan memaparkan bagaimana bahan ajar yang dihasilkan pada tiap tipe keterpaduan Robin Fogarty. Artikel ini dapat sebagai dasar rujukan dalam penelitian pengembangan bahan ajar IPA terpadu menggunakan model tipe keterpaduan Robin Fogarty. Bahan ajar IPA dengan berbagai keterpaduan ini diharapkan dapat meningkatkan minat dan motivasi belajar siswa dalam pembelajaran IPA terpadu di Sekolah Menengah Pertama (SMP) [12].

\section{METODE PENELITIAN}

Jenis penelitian ini adalah literature review. Tinjauan literatur adalah analisis, evaluasi kritis dan sintesis pengetahuan yang ada yang relevan dengan masalah penelitian Anda, tesis atau masalah yang ingin Anda sampaikan [27]. Pada artikel ini kami melakukan literature review tentang integrasi bahan ajar IPA menggunakan model keterpaduan Robin Fogarty yang terdiri dari model terpisah (fragmented), keterkaitan / keterhubungan (connected), berbentuk sarang (nested), dalam satu rangkaian (sequenced), terbagi (shared), bentuk jaring laba- laba (webbed), dalam satu alur (threaded), terpadu (integrated), tenggelam (immersed), membentuk jejaring (networked).

\section{HASIL DAN PEMBAHASAN}

Menurut Robin Fogarty terdapat 10 model pembelajaran terpadu yang dapat diterapkan dalam pengembangan bahan ajar IPA yaitu model terpisah (fragmented), keterkaitan / keterhubungan (connected), berbentuk sarang (nested), dalam satu rangkaian (sequenced), terbagi (shared), bentuk jaring laba- laba (webbed), dalam satu alur (threaded), terpadu (integrated), tenggelam (immersed), membentuk jejaring (networked) [19, 21, 22]. Model pembelajaran terpadu dari Robin Fogarty ini diterapkan dalam pengembangan bahan ajar IPA. Penelitian pengembangan bahan ajar IPA sering kali menyertakan tipe keterpaduan yang digunakan. Ada banyak tema, metode pengembangan yang digunakan dalam pengembangan bahan ajar IPA. Ada juga yang mengembangkan bahan ajar IPA dalam satu topik saja.Dengan demikian dihasilkan bahan ajar IPA dengan berbagai macam model keterpaduan. Sehingga diharapkan dapat digunakan guru dalam pembelajaran IPA terpadu di SMP/ MTs. Sepuluh macam model keterpaduan Robin Fogarty dapat di lihat pada Gambar 1. 


\section{Ten Views for Integrating Curriculum}

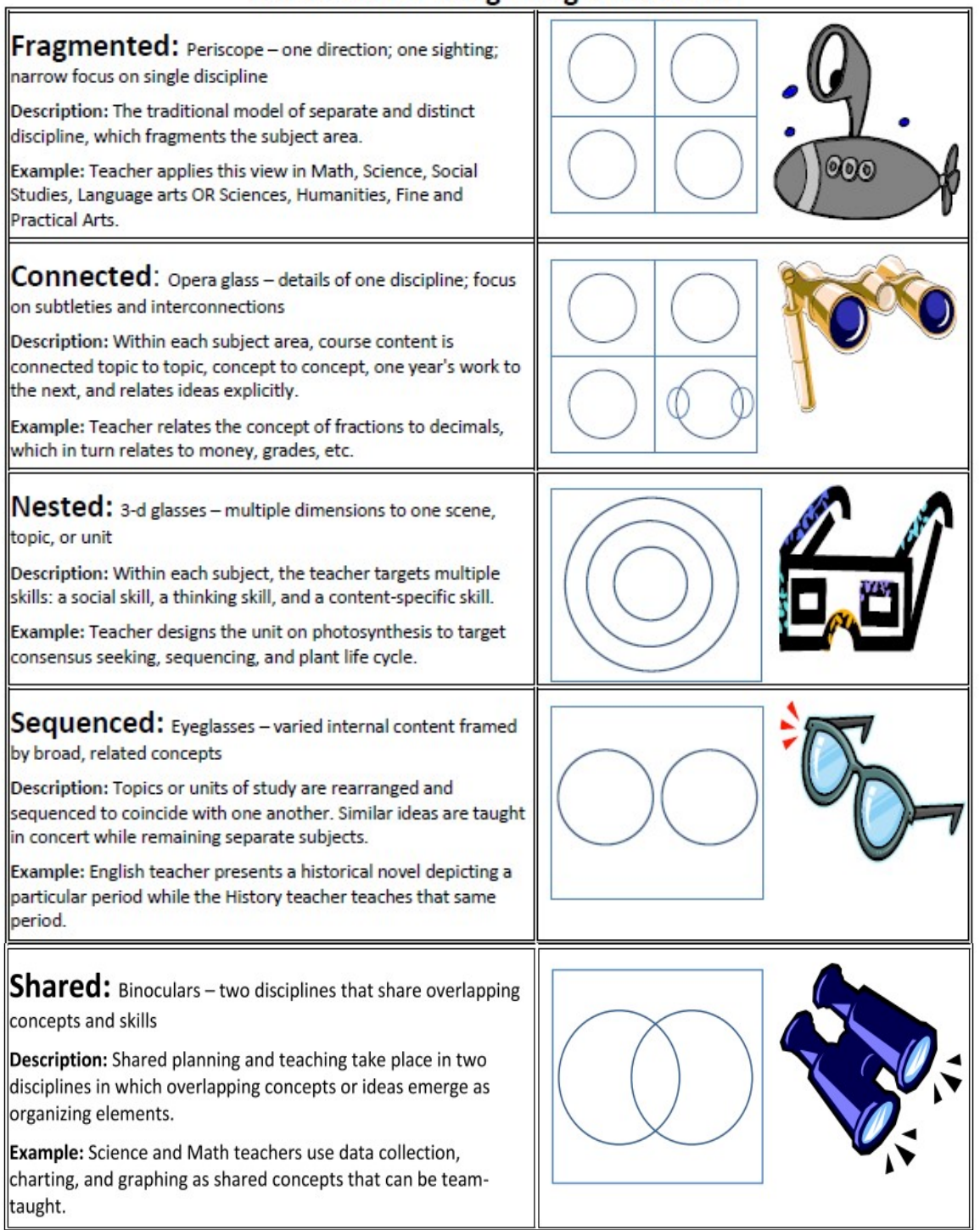

Webbed: Telescope - broad view of an entire constellation as one theme, webbed to the various elements

Description: A fertile theme is webbed to curriculum contents and disciplines; subjects use the theme to sift out appropriate concepts, topics, and ideas.

Example: Teacher presents a simple topical theme, such as the circus, and webs it to other subject areas.

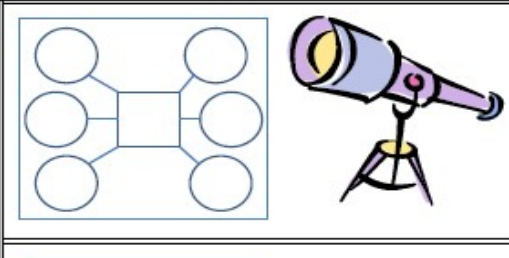

Threaded: Magnifying glass - big ideas that magnify all content through a metacurricular approach

Description: The metacurricular approach threads thinking skills, social skills, multiple intelligences, technology, and study skills through the various disciplines.

Example: Teaching staff targets prediction in Reading, Math, and Science while Social Studies teacher targets forecasting current events.

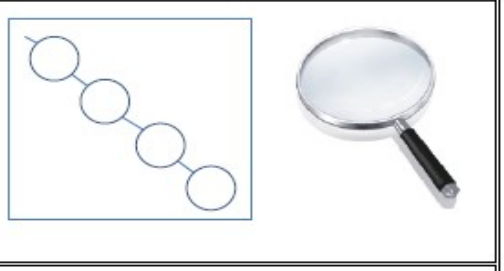




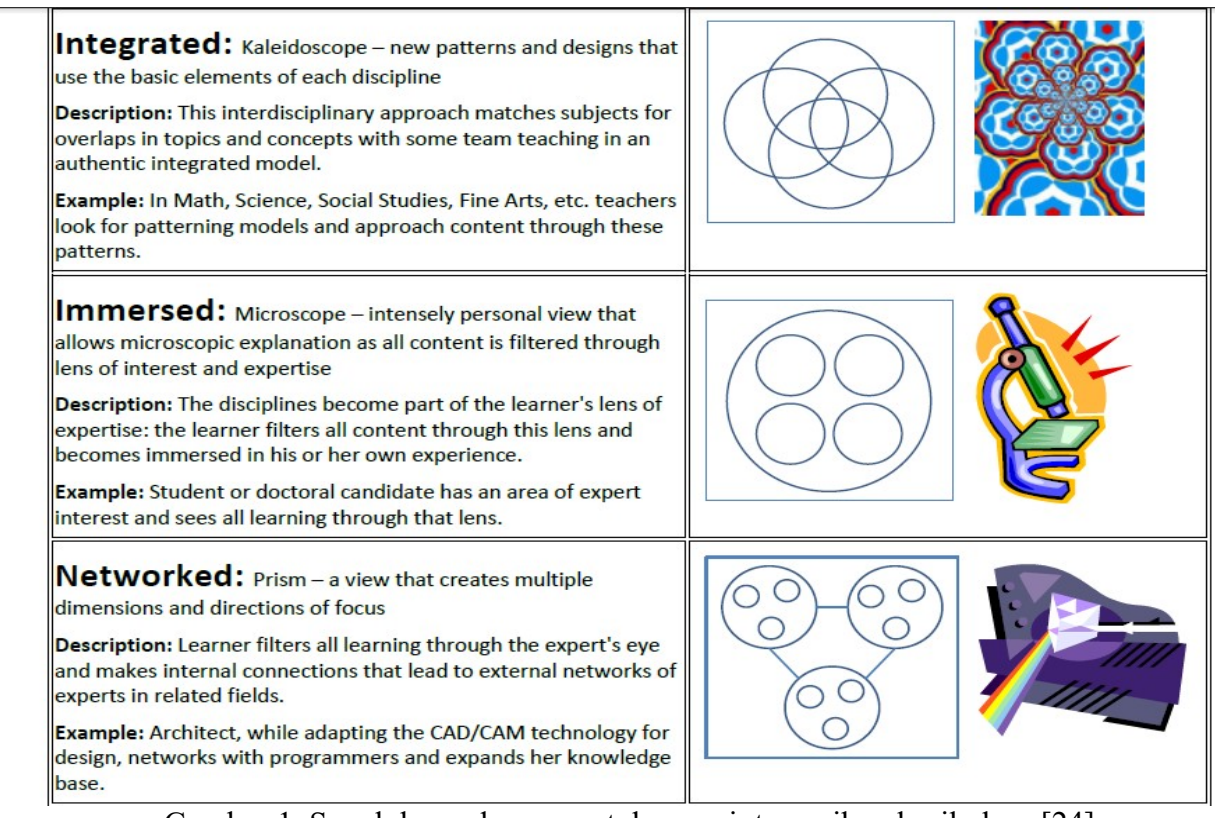

Gambar 1. Sepuluh pandangan untuk mengintegrasikan kurikulum [24]

\section{Model IPA Tipe Terpisah (Fragmented)}

Model keterpaduan tipe terpisah (fragmented) disebut juga kurikulum mata pelajaran terpisah (Separated Subject Curriculum). Separate-subject curriculum merupakan kurikulum yang bahan pelajarannya disajikan dalam subject atau mata pelajaran yang terpisah-pisah. Model ini menyajikan materi pelajaran terpisah antara kimia, fisika, biologi dan IPBA [21]. Model ini berfokus pada prioritas setiap mata pelajaran $[19,21]$.

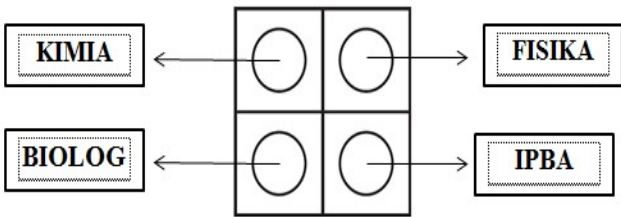

Gambar 2. Model IPA Terpadu Tipe Fragmented

Pada model IPA terpadu tipe fragmented ini materi IPA (kimia, fisika, biologi dan IPBA) disusun secara terpisah satu sama lain. Model tipe fragmented ini belum pernah digunakan dalam pengembangan bahan ajar IPA terpadu karena model ini belum memberikan keterkaitan antar kajian ilmu IPA (kimia, fisika, biologi dan IPBA) dalam bahan ajar tersebut. Jadi kurang tepat dijadikan suatu model keterpaduan dalam pembelajaran dan pengembangan bahan ajar IPA terpadu.

\section{Model IPA Tipe Keterkaitan (Connected)}

Model keterhubungan (connected) mempunyai karakteristik menghubungkan satu konsep dengan konsep lain, topik dengan topik lain, satu keterampilan dengan keterampilan lain, ide yang satu dengan ide yang lain tetapi masih dalam lingkup satu bidang studi [42]. Keterpaduan pola Connected ini dapat membantu siswa mengembangkan konsepkonsep kunci secara terus menerus, sehingga terjadi proses internalisasi [32]. Fokus model connected adalah pada keterkaitan dalam seluruh bidang, keterkaitan antar topik, keterkaitan antar konsep, keterkaitan antar keterampilan, mengaitkan tugas pada hari ini dengan selanjutnya bahkan ide-ide yang dipelajari pada satu semester dengan ide-ide yang dipelajari pada semester berikutnya dalam satu bidang studi [12, 13, 19, 21-23].

Model connected memiliki kelebihan yaitu dapat memotivasi siswa dan membantu siswa untuk melihat keterhubungan antar gagasan, dengan tema yang digunakan tetap terfokus pada satu disiplin ilmu.

\section{MODEL IPA TERPADU TIPE CONNECTED}

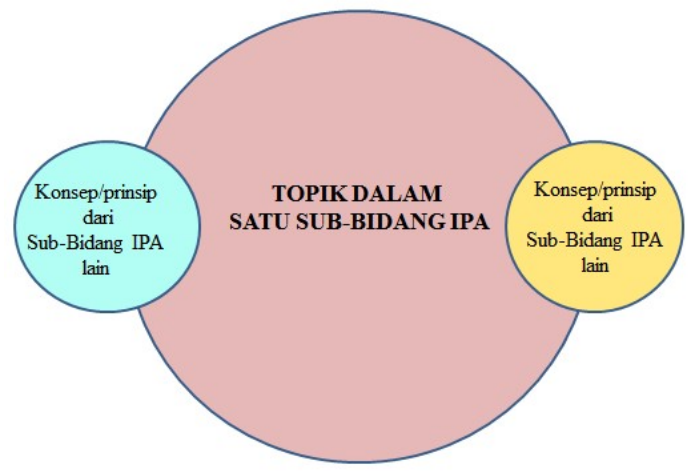

Gambar 3. Model IPA Terpadu Tipe Connected [18]

Pengembangan bahan ajar IPA menggunakan model IPA terpadu tipe connected maka materi IPA 
(kimia, fisika, biologi dan IPBA) disusun secara terpisah. Tetapi terdapat sedikit keterkaitan antar materi IPA. Ada kaitan sedikit antara kimia dan biologi, fisika dan kimia atau fisika dan biologi. Sebagai contoh dapat dilihat pada Gambar 4 berikut. Model IPA terpadu tipe connected antara IPBA, Kemagnetan dan Migrasi Hewan.

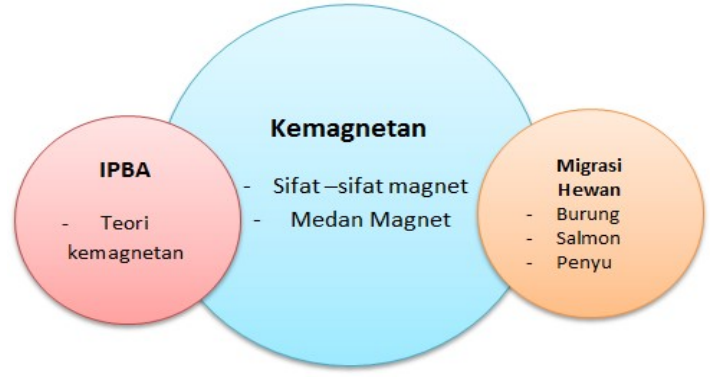

Gambar 4 . Model IPA terpadu tipe connected antara IPBA, Kemagnetan dan Migrasi Hewan

\section{Model IPA Tipe Sarang (Nested)}

Pembelajaran terpadu model nested (tersarang) adalah model pembelajaran yang mengintegrasikan kurikulum di dalam satu disiplin ilmu secara khusus meletakkan fokus pengintegrasian pada sejumlah keterampilan belajar yang ingin dilatihkan oleh seorang guru kepada siswanya dalam suatu unit pembelajaran untuk ketercapaian materi pelajaran (content) [15] . Model ini menargetkan keterampilan dan konsep multidimensi ke dalam satu pelajaran [19]. Pembelajaran masih dalam sub-bidang-sub-bidang IPA secara terpisah. Fokus pada konten sains, keterampilan berpikir, keterampilan sosial, dan keterampilan lain [18].

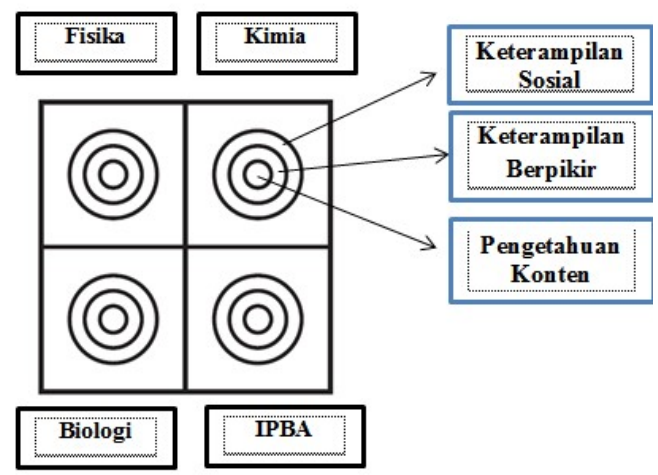

Gambar 5. Model IPA Terpadu Tipe Nested

Keunggulan dari model Nested yaitu pembelajaran lebih kaya, karena di samping mengembangkan pengetahuan, juga mengembangan keterampilan berpikir, keterampilan sosial, dll. secara bersamaan. Sedangkan kelemahan dari model Nested ini yaitu ketika menyarangkan dua, tiga, dan lebih sasaran pembelajaran dapat membuat siswa bingung, jika penyarangan tidak dilaksanakan secara hati-hati [18]. Pengembangan bahan ajar IPA menggunakan model IPA terpadu tipe nested maka materi IPA (kimia, fisika, biologi dan IPBA) disusun secara terpisah satu sama lain. Pada setiap materi IPA memuat pengetahuan konten, keterampilan berpikir dan keterampilan sosial.

\section{Model IPA Tipe Berurutan (Sequenced)}

Mengatur ulang urutan ketika suatu topik diajarkan bertepatan dengan paralel topik dalam disiplin lain [19]. Topik atau unit studi disusun kembali dan diurutkan bertepatan satu sama lain. Ide-ide serupa diajarkan dengan rinci sementara tetap menjadi subjek yang terpisah. Dua disiplin terkait dapat diurutkan sehingga isi subjek dari keduanya diajarkan secara paralel sesuai dengan urutan topik diajarkan. Intinya, satu subjek membawa yang lain dan sebaliknya. Model Sequenced ini adalah model pertama yang guru disiplin ilmu yang terpisah (fisika, biologi, kimia dan IPBA) perlu kolaboratif untuk merencanakan dan mengurutkan beberapa ide yang serupa / terkait.[19].

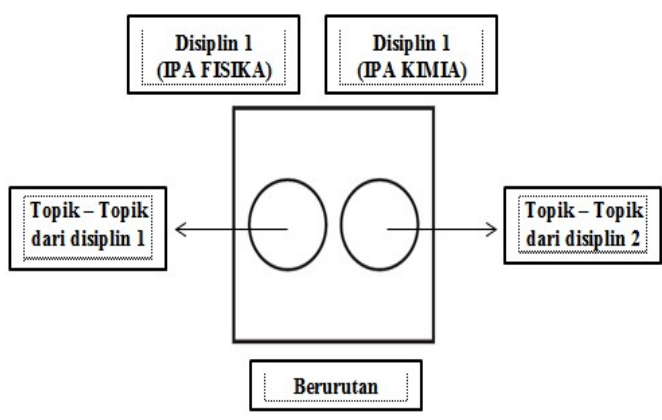

Gambar 6. Model IPA Terpadu Tipe Sequenced

Keunggulan dari model sequenced ini yaitu :

1. Materi pelajaran dalam bidang-bidang dalam sains terurut secara logis.

2. Konsep prasyarat mendahului konsep utama.

3. Konsep dasar mendahului aplikasi konsep.

4. Konsep umum mendahului konsep spesifik.

Keterbatasan dari model sequenced ini yaitu Memerlukan fleksibiltas guru dan kemitraan dan kolaborasi yang erat antarguru dari disiplin berbeda dalam sains (phi dan bio, kim dan bio, dsb.)[19, 21].

Pengembangan bahan ajar IPA menggunakan model IPA terpadu tipe sequenced maka materi IPA (kimia, fisika, biologi dan IPBA) disusun secara berurutan berdasarkan topik - topik terkait dalam setiap disiplin IPA. 


\section{Model IPA Tipe Bersero (Shared)}

Pembelajaran terpadu tipe shared adalah pembelajaran terpadu yang merupakan gabungan atau keterpaduan antara dua mata pelajaran yang saling melengkapi dan didalam perencanaan atau pengajarannya menciptakan satu fokus pada konsep, keterampilan serta sikap [16, 51]. Pembelajaran IPA Terpadu tipe Shared mengutamakan pemahaman antar bidang studi karena memfokuskan pada isi pelajaran, strategi berpikir dan keterampilan sosial [51]. Pasangan ini mengidentifikasi prioritas masingmasing, mereka mencari tumpang tindih dalam konten konten. Topik dan unit dari dua disiplin terkait menawarkan kemungkinan integrasi yang kaya dengan mengidentifikasi konsep dasar, keterampilan, dan sikap yang tumpang tindih. Misalnya, ilmu biologi dan guru ilmu fisika menggunakan konsep frekuensi, sikap akurasi, dan keterampilan mengukur sebagai ide yang dibagikan yang dapat diajarkan tim $[18,33]$.

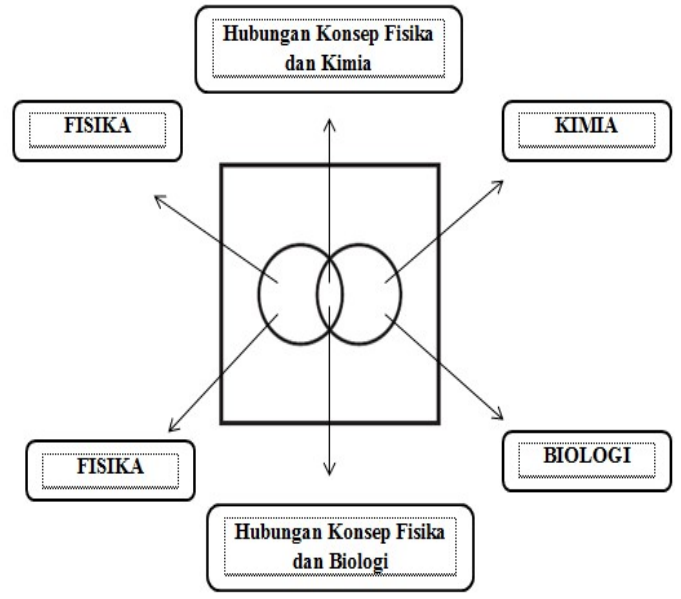

Gambar 7. Model IPA Terpadu Tipe Shared

Keterkaitan antara 2 konsep IPA yang diintegrasikan mencakup konsep, keterampilan dan sikap. Sebagai contoh dapat dilihat pada Gambar 8 integrasi antara fisika dan biologi yang mencakup konsep, keterampilan dan sikap.

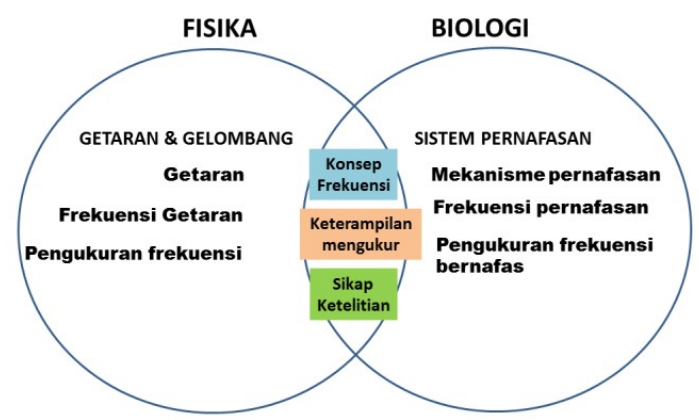

Gambar 8. Model IPA Terpadu Tipe Shared antara Fisika dan Biologi [18].
Keunggulan dari model shared ini yaitu :

1. Menunjukkan keterpaduan bidang-bidang IPA dalam aspek konsep, keterampilan, dan sikap.

2. Karena melibatkan dua guru dalam satu tim, maka lebih mudah tercipta kolaborasi dalam merancang dan melaksanakan pembelajaran.

3. Materi pelajaran lebih kontekstual.

Model shared ini Dapat dilakukan secara baik hanya jika tersedia waktu, fleksibilitas, komitmen, dan kompromi tim guru [18]. Pengembangan bahan ajar IPA menggunakan model IPA terpadu tipe shared maka materi IPA (kimia, fisika, biologi dan IPBA) disusun dengan adanya keterkaitan antar 2 disiplin ilmu IPA. Pada model ini sudah mulai mengaitkan konsep - konsep dari 2 disiplin ilmu IPA. Misal mengaitkan kimia dan fisika, biologi dan kimia atau fisika dan biologi sesuai dengan pokok bahasan yang sedang dikembangkan. Pada pokok bahasan tertentu ditentukan konsep - konsep apa yang memiliki keterkaitan dan disusunlah suatu bahan ajar yang memiliki keterkaitan antara 2 disiplin ilmu IPA tersebut.

\section{Model IPA Tipe Jaring Laba- Laba (Webbed)}

Pembelajaran tematik model Webbed adalah model pembelajaran terpadu yang menggunakan pendekatan tematik yang dimulai dengan menentukan tema tertentu $[13,47,48,50]$. Tema yang ditentukan dapat memadukan konsep - konsep dari sejumlah KD pada mata pelajaran IPA Terpadu $[45,46]$. Penggunaan tema sebagai penghubung antar materi dalam satu bidang studi dapat membuat peserta didik memperoleh pengetahuan dan keterampilan secara utuh sehingga pembelajaran menjadi bermakna [42]. Selain itu, pembelajaran tematik membuka peluang yang sangat besar untuk penciptaan situasi belajar yang berpusat pada siswa (student centre) [50]. Sehingga dapat membantu mengembangkan kemampuan berpikir siswa, dimana siswa dihadapkan pada konsep-konsep yang dapat ditinjau dari berbagai bidang studi, dari berbagai sudut pandang atau disiplin keilmuan fisika, kimia, dan biologi yang mudah dipahami dan dikenal siswa $[2,3,50]$. Berfokus pada suatu tema yang subur (fertile theme) yang memungkinkan pembentukan jejaring dengan materi (konten) IPA-Biologi, IPAFisika dan IPA-Kimia, dan IPA-IPBA.

Keunggulan dari model webbed ini yaitu :

1. Dengan memberikan kesempatan bagi untuk memilih tema yang menarik perhatian peserta didik, pembelajaran akan lebih memotivasi peserta didik. 
2. Memberikan peluang kepada peserta didik untuk memahami keterkaitan antardisiplin dalam IPA.

3. Memungkinkan pelaksanaan pembelajaran kolaboratif (kerjasama).

Keterbatasan dari model webbed ini yaitu :

1. Sukar untuk memilih tema yang yang memungkinkan semua disiplin IPA terkait.

2. Sering terjadi kegiatan pembelajaran lebih berfokus pada keterkaitan antar disiplin IPA daripada pembelajaan konsep secara mendalam. Kedua dimensi pembelajaran IPA terpadu, yakni keterkaitan antar bidang IPA dan pemahaman konsep-konsep yang mendalam, perlu menjadi fokus perhatian guru [18].

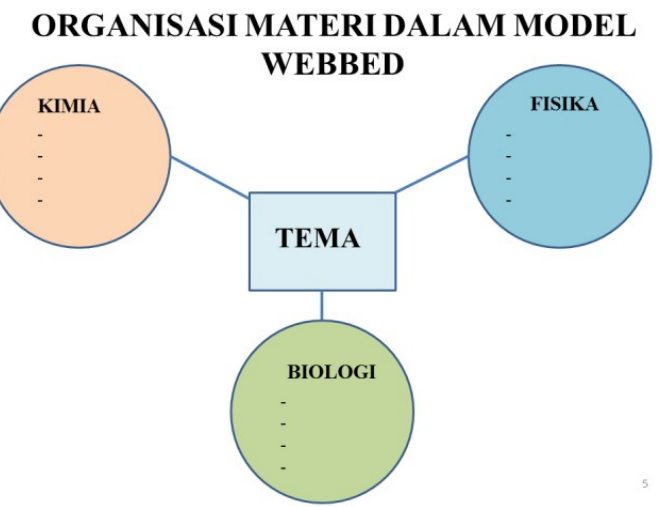

Gambar 9. Model IPA Terpadu Tipe Webbed Kimia, Fisika dan Biologi

ORGANISASI MATERI DALAM MODEL

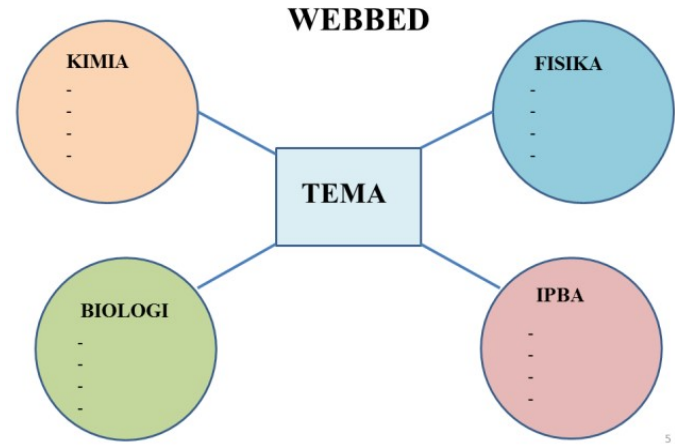

Gambar 10. Model IPA Terpadu Tipe Webbed

Kimia, Fisika, Biologi dan IPBA

Pengembangan bahan ajar IPA menggunakan model IPA terpadu tipe webbed maka materi IPA (kimia, fisika, biologi dan IPBA) disusun berdasarkan tema yang telah ditentukan. Langkah awal dalam mengembangkan bahan ajar IPA menggunakan model webbed ini yaitu dengan menentukan tema. Tema yang dipilih yaitu tema yang memiliki keterkaitan dengan disiplin ilmu IPA. Tema yang biasanya digunakan seperti tema laut, sungai, gunung, pupuk, sampah, hujan, air, dan lain sebagainya. Setelah penentuan tema ditentukan kaitan tema dengan konsep masing- masing disiplin ilmu IPA. Maka dikembangkan lah bahan ajar IPA berdasarkan keterkaitan sesuai tema tersebut. Sebagai contoh dapat dilihat pada Gambar 11 model IPA terpadu tipe webbed dengan tema pupuk.

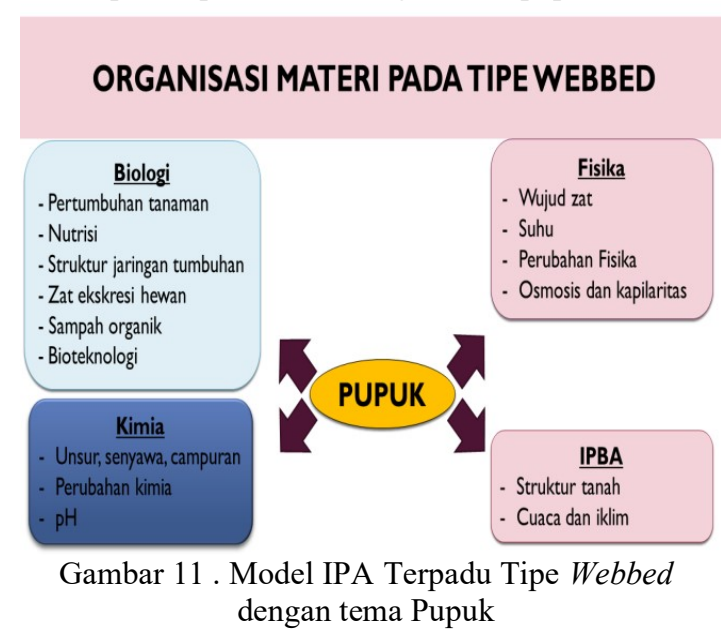

\section{Model IPA Tipe Galur (Threaded)}

Keterampilan berpikir, keterampilan proses, keterampilan sosial, keterampilan rekayasa (engineering) dialurkan melalui semua bidang disiplin dalam IPA (Bio, fis, kim, IPBA). Pola integrasi IPA berfokus pada metakurikulum yang mengurutkan atau menyambungkan hal-hal yang inti dari semua materi pelajaran. Keterampilan berpikir atau keterampilan proses digalurkan ke dalam materi pelajaran bidang-bidang disiplin dalam IPA $[5,18$, $19,21,22,24]$.

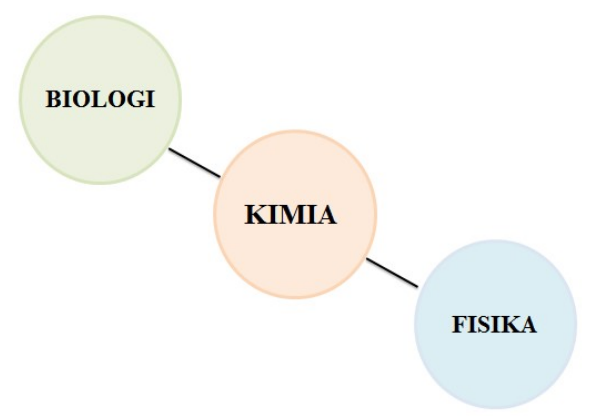

Gambar 12. Model IPA Terpadu Tipe Threaded

Keunggulan dari model threaded ini diantaranya yaitu :

1. Mengembangkan konsep metakurikulum, dan kepedulian pada keterampilan berpikir yang dikembangkan pada diri siswa di sebalik materi (content) pelajaran.

2. Guru menekankan perilaku metakognitif, sehingga siswa belajar bagaimana mereka belajar (to learn how they learn). 
3. Membuat siswa sadar akan keterampilan yang "tranferable" dari satu disiplin ke disiplin lain.

4. Integrasi bukan hanya pada konten, melainkan pengembangan keterampilan yang dibawa oleh konten.

Keterbatasan dari model threaded ini diantaranya yaitu :

1. Nampak menambah kurikuluim

2. Koneksi materi pelajaran antardisiplin tidak diajarkan secara eksplisit dan tidak mendapat penekanan.

3. Mempersyaratkan guru memahami kepeterampilan-keterampilan yang potensial dibawa oleh konten mata pelajaran

Pengembangan bahan ajar IPA menggunakan model IPA terpadu tipe threaded maka materi IPA (kimia, fisika, biologi dan IPBA) disusun secara alur. Keterampilan berpikir, keterampilan proses, keterampilan sosial, keterampilan rekayasa (engineering) dialurkan melalui semua bidang disiplin dalam IPA (Bio, fis, kim, IPBA). Sebagai contoh dapat dilihat pada Gambar 13 berikut model IPA terpadu tipe Threaded antara kimia, IPBA dan biologi dengan keterampilan proses sains mengintegrasikan.

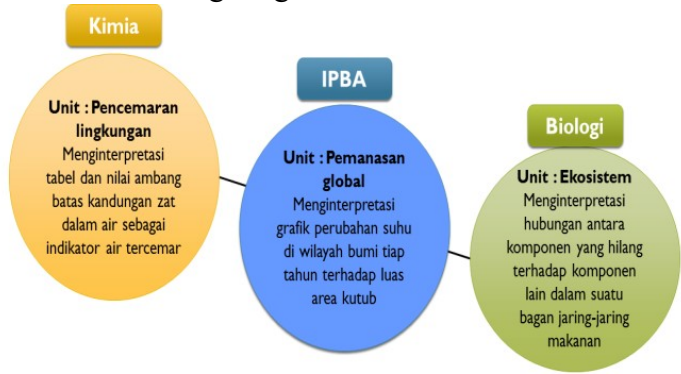

Gambar 13. IPA Terpadu Tipe Threaded antara

Kimia, IPBA dan Biologi menggunakan keterampilan proses sains mengintegrasikan

\section{Model IPA Tipe Terintegrasi Penuh (Integrated)}

Model pembelajaran ini menggunakan pendekatan antar mata pelajaran yang dipadukan. Beberapa mata pelajaran dicari konsep, sikap, dan ketrampilan yang tumpang tindih dipadukan menjadi satu. Kegiatan guru pertama menyeleksi konsep, nilai-nilai dan ketrampilan yang memiliki keterkaitan erat satu sama lain dari berbagai mata pelajaran. Keuntungan medel pembelajaran ini bagi peserta didik adalah lebih mudah mengaitkan materi pembelajaran dari berbagai mata pelajaran. Model inilah yang dikembangkan sebagai pembelajaran tematik terpadu di kurikulum 2013 [30]. Model Integrated merupakan perluasan dari model "shared". Tipe integrasi ini menggambarkan pendekatan lintas disiplin. Tipe terpadu meleburkan semua disiplin dalam IPA, dengan memilih prioritas dari masing-masing disiplin dan menemukan overlapping skills, konsep, sikap dari semua disiplin tersebut. Model ini menuntut kecanggihan dalam perencanaan dan implementasi, sehingga perlu dilakukan melalui "team teaching" [19, 21, 22, 39].

Keunggulan dari model integrated diantaranya yaitu:

1. Mereduksi jumlah materi pembelajaran sehingga terhindar dari gejala "sarat materi”.

2. Mengembangkan kemampuan berpikir holistik.

3. Menciptakan kebersamaan guru antardisiplin dalam merencanakan dan melaksanakan pembelajaran.

Keterbatasan dari model integrated ini diantaranya yaitu :

1. Menuntut kepakaran tinggi guru-guru dalam merancang pembelajaran, khususnya dalam memilih konsep, keterampilan, sikap yang diprioritaskan dalam bidang disiplindisiplinnya.

2. Memerlukaan komitmen dan kesediaan bekerjasama antarguru IPA.

3. Perlu merestrukturisasi jadwal pelajaran untuk mengimplementasikannya.

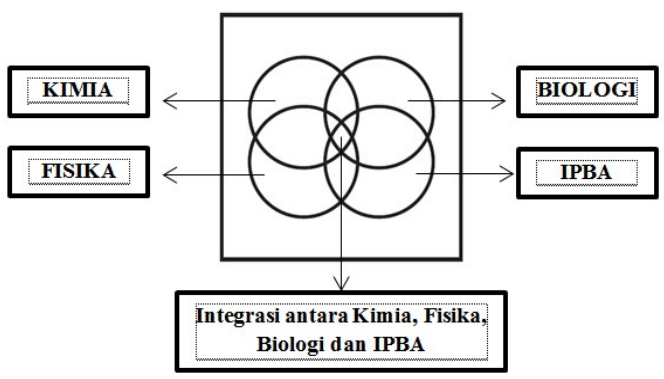

Gambar 14. Model IPA Terpadu Tipe Integrated

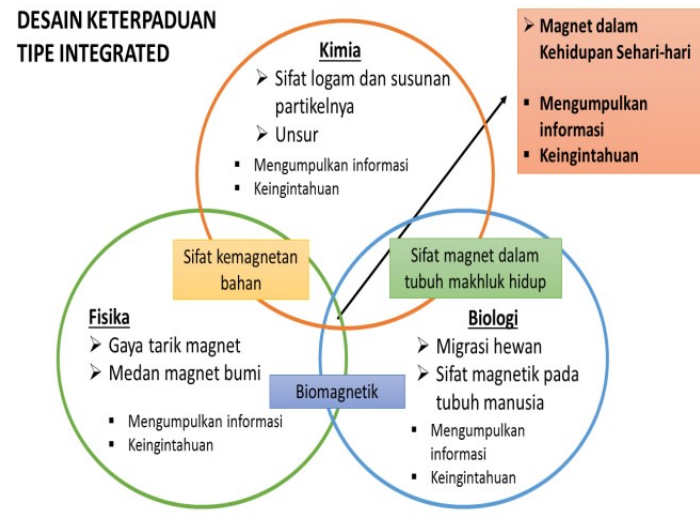

Gambar 15. Model IPA Terpadu tipe Integrated antara Kimia, Fisika dan Biologi 
Pengembangan bahan ajar IPA menggunakan model IPA terpadu tipe threaded maka materi IPA (kimia, fisika, biologi dan IPBA) disusun terpadu yaitu adanya hubungan antar 2 disiplin ilmu, 3 disiplin ilmu dan keempat disiplin ilmu IPA. Selain itu juga terdapat integrasi atau keterpaduan dari keterampilan dan sikap yang ingin dikembangkan dalam bahan ajar IPA. Sebagai contoh dapat dilihat pada Gambar 15 tipe integrated antara kimia, fisika dan biologi.

\section{Model IPA Tipe Tenggelam (Immersed)}

Menghubungkan pengalaman masa lalu dan pengetahuan sebelumnya dengan informasi baru yang diperoleh dari pembelajaran[20]. Model immersed adalah model pembelajaran terpadu yang berpusat untuk memadukan kebutuhan siswa/ mahasiswa dimana mereka akan melihat apa yang dipelajarinya dari minat dan pengalaman mereka sendiri. Setiap siswa bebas untuk menentukan konsep - konsep apa saja yang ingin dipelajarinya. Setiap siswa menentukan sendiri konsep yang ingin ia pelajari, mereka tuliskan pemahaman awal mereka, mereka mencari tau sendiri konsep tersebut pada sumber belajar yang ada dan siswa menentukan sendiri konsep yang benar dari konsep yang mereka minati tersebut.

\section{CONTOH DESAIN MODEL TERBENAM}

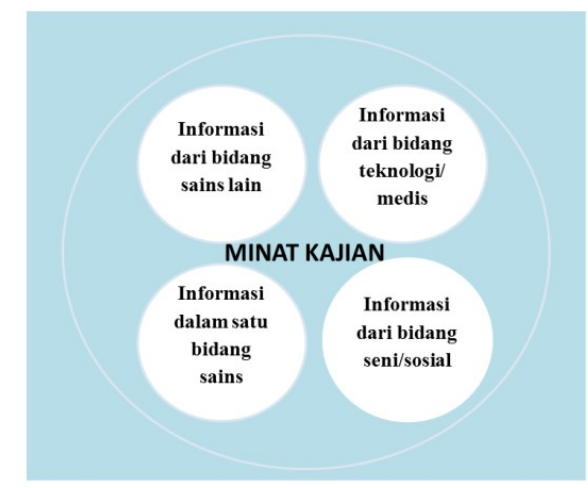

Gambar 16. Model IPA Terpadu Tipe Immersed

Pengembangan bahan ajar IPA menggunakan model IPA terpadu tipe immersed maka materi IPA (kimia, fisika, biologi dan IPBA) disusun dengan memadukan setiap data dari tiap bidang dan disiplin dengan menyalurkan ide - ide melalui bidang yang sangat diminatinya. Bahan ajar IPA terpadu menggunakan model Immersed ini terdiri dari bagian - bagian kosong yang dapat digunakan siswa untuk menentukan suatu konsep yang diminati. Dimulai dari bagian kosong konsep yang diminati siswa dalam satu bab IPA. Bagian kosong kedua siswa diminta untuk menuliskan konsep tersebut. Setelah siswa membaca berbagai sumber belajar mencari tau konsep yang benar dari yang mereka minati, selanjutnya terdapat bagian kosong untuk konfirmasi konsep. Begitu seterusnya untuk setiap bab. Memang agak susah menerapkan pembelajaran IPA terpadu menggunakan tipe immersed ini dikarenakan pembelajaran di Indonesia terikat pada tuntutan kurikulum. Sedangkan pada pembelajaran IPA terpadu tipe immersed ini siswa bebas memilih konsep mana saja yang ingin ia pelajari. Jadi memiliki kemungkinan besar tidak semua konsep IPA dipelajari oleh setiap siswa. Siswa yang memiliki ketertarikan yang berbeda tentunya juga memiliki pengetahuan konsep yang berbeda. Siswa yang memiliki minat lebih ke biologi tentunya ia akan memilih konsep IPA yang memiliki kaitan dengan biologi. Begitupun dengan siswa yang memiliki minat fisika akan memilih konsep IPA yang banyak kaitannya dengan fisika. Sehingga setiap siswa memiliki persentase yang berbeda - beda jumlah konsep IPA yang dipelajari.

\section{Model IPA Tipe Jejaring (Networked)}

Pembelajaran IPA terpadu tipe networked merupakan pembelajaran yang memberikan kesempatan bagi peserta didik menerima masukan dari luar dirinya yang ia pandang sebagai pakar (expert), sehingga idenya mengalami penghalusan, penyempurnaan, dan perkembangan secara berkelanjutan. Dalam mengembangkan pengetahunannya, peserta didik menjadikan jejaring sebagai sumber utama yang harus difilter dengan lensa dan minatnya $[18,19,21]$. Dengan tipe integrasi jejaring peserta didik secara langsung mengintegrasikan IPA melalui proses pemilihan oleh dirinya (self-selection) jejaring yang diperlukan [22].

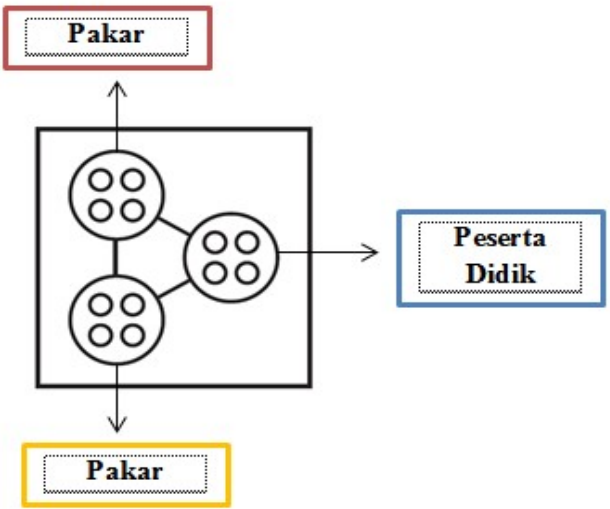

Gambar 17. Model IPA Terpadu Tipe Networked

Pengembangan bahan ajar IPA menggunakan model IPA terpadu tipe Networked sebenarnya hampir sama dengan bahan ajar IPA terpadu tipe immersed. Perbedaan antara bahan ajar tipe networked dan immersed terletak pada proses penggalian informasi terkait konsep yang mereka minati. Setelah siswa menentukan konsep yang mereka minati, siswa menggali informasi terkait konsep tersebut dengan bertanya pada temannya dan 
guru. Sedangkan pada tipe immersed tadi siswa menggali informasi sendiri melalui sumber belajar yang ada.

Keunggulan dari model networked diantaranya yaitu:

1. Pendekatan pembelajaran terpadu yang memberi kesempatan bagi perserta didik untuk proaktif, melakukan insiasi-diri (selfinitiation) untuk mengembangkan pengetahuannya.

2. Peserta didik distimulasi dengan informasi, keterampilan, atau konsep-konsep yang relevan ia mengalami pembelajaran.

3. Inisiasi belajar muncul dari dalam.

Kelemahan dari model networked diantaranya yaitu:

1. Model ini memadai bagi peserta didik yang bermotivasi.

2. Melimpahnya informasi dari pakar dapat mengurangi minat awal dan membuyarkan fokus kajian.

\section{KESIMPULAN}

Terdapat 10 model pembelajaran terpadu yang dapat diterapkan dalam pengembangan bahan ajar IPA yaitu model terpisah (fragmented), keterkaitan / keterhubungan (connected), berbentuk sarang (nested), dalam satu rangkaian (sequenced), terbagi (shared), bentuk jaring laba- laba (webbed), dalam satu alur (threaded), terpadu (integrated), tenggelam (immersed), membentuk jejaring (networked). Tiap tipe keterpaduan menghasilkan bahan ajar IPA yang berbeda. Bahan ajar yang dihasilkan dapat digunakan dalam pembelajaran IPA terpadu di SMP dengan menyesuaikan model pembelajaran yang akan digunakan. Perlu penguasaan konsep IPA yang baik dalam penyusunan bahan ajar IPA terpadu untuk setiap tipe nya. Sebelum mengembangkan bahan ajar IPA terpadu dengan menggunakan salah satu tipe keterpaduan, peneliti harus memahami terlebih dahulu tipe keterpaduan yang akan digunakan.

\section{DAFTAR PUSTAKA}

[1] Amaliya Kurniawati, Suliyanah, A.Q. (2013). Pengembangan Bahan Ajar IPA Terpadu Tema Letusan Gunung Berapi Kelas VII di SMP Negeri 1 Kamal. Jurnal Pendidikan Sains e-Pensa, 1 (1). 42-46

[2] Akmalia Ma'rifathur Rizqi, Parmin, S.N. (2013). Pengembangan Modul IPA Terpadu Berkarakter Tema Pemanasan Global Untuk Siswa SMP/MTs. Unnes Science Education Journal, 2(1). 203-208.[2] .

[3] Anis Zaqiyyatun Nafsi, Hermin Budiningarti, M. (2013). Penerapan Model Direct Instruction Dengan Teknik Mind Mapping
Pada Tema Perkaratan Logam Besi Untuk Meningkatkan Hasil Belajar Siswa. Jurnal Pendidikan Sains e-Pensa, 1(2).110-117.

[4] Asrizal .(2015). Studi Pendahuluan Tentang Permasalahan dan Kesiapan Guru Untuk Mengimplementasikan Pembelajaran IPA Terpadu Pada Siswa SMP. Eksakta, 2. 57-65.

[5] Barbara Moss, H.N. (2014). Creating Integrated Curriculum: Books to guide the Process. International Reading Association, 40(4). 64-65.

[6] Beaumont-Walters, Y. and Soyibo, K. (2014). An Analysis of High School Students' Performance on Five Integrated Science Process Skills. Research in Science \& Technological Education., 19( 2). 133-145. DOI:https://doi.org/10.1080/02635140120087 687.

[7] Costley, K.C. (2015). Research Supporting Integrated Curriculu : Evidence for Using This Method of Instruction in Public School Classrooms. Running Head: Integrated Curriculum, 1-11.

[8] Dewi, C. (2010). Implementasi Sistem Pembelajaran Terpadu Di Sekolah Dasar Islam Terpadu (SDIT) Ar-risalah Surakarta.

[9] Dhesta Nurdana Puspita, Wahono Widodo, S.A. (2013). Penerapan Pembelajaran IPA Terpadu Dengan Pendekatan Contextual Teaching and Learning (CTL) Materi Bunyi dan Pendengaran Pada Siswa SMP. Jurnal Pendidikan Sains e-Pensa, 1(2).188-193.

[10] Dian Khoirul Huda, Supriyono, A.Q. (2013). Penerapan ipa terpadu tipe Connected Dengan Model Cooperative Learning Untuk Meningkatkan Hasil Belajar Siswa Pada Materi Perubahan Fisika dan Kimia Di SMP Muhammadiyah 6 Surakarta. Jurnal Pendidikan Sains e-pensa,1(2). 95-102.

[11] Dian Sulistyowati, Fida Rachmadiarti, B.S. (2013). Penerapan Strategi Pembelajaran Generatif Pada Pembelajaran IPA Terpadu Tema Rokok Untuk Meningkatkan Hasil Belajar Siswa SMP Kelas VII. Jurnal Pendidikan Sains e-pensa, 1(2)174-180.

[12] Drake, B.S.M. and Reid, J. (2010). Integrated Curriculum. The Literacy and Numeracy Secretariat, 28. 5-8.

[13] Drake, S. 1991. How Our Team Dissolved the Boundaries. Educational leadership, 49(2). 20-22.

[14] Van Driel, J.H. et al. (2001). Professional development and reform in science education: The role of teachers' practical knowledge. Journal of Research in Science Teaching, 38(2). 137-158.

[15] Duiningrum, I. (2018). Pengembangan Perangkat Pembelajaran IPA Terpadu Model Nested Untuk Meningkatkan Kemampuan 
Kognitif, Rasa Ingin Tahu dan Keterampilan Mengorganisasi Ide Peserta Didik SMP. EJournal Pendidikan IPA, 1. 27-32.

[16] Ekapti, R.F. and Ahied, M. (2016). Konsepsi Siswa Smp Dalam Pembelajaran Ipa Terpadu Tipe Shared Konsep Tekanan. Seminar Nasional Pendidikan Sains ,147-154.

[17] Ervian Arif Muhafid, Novi Ratna Dewi, A.W. (2013). Pengembangan Modul IPA Terpadu Berpendekatan Keterampilan Proses Pada Tema Bunyi di SMP Kelas VIII. Unnes Science Education Journal, 2 (1).140-148.

[18] Firman, H. 2018. Pembelajaran IPA Terpadu. Universitas Pendidikan Indonesia.

[19] Fogarty, R. 1991. How to integrate the curricula. IRI/SKylight Publishing, Inc.

[20] Fogarty, R. 1991. How to integrate the curricula.

[21] Fogarty, R. 1991. Ten Ways to Integrate Curri. Educational Leadership. October (1991).

[22] Fogarty, R. 1991. The Mindful School How To Integrate The Curricula. IRI/SKylight Publishing, Inc.

[23] Fogarty, R. and McTighe, J. (2015). Educating teachers for higher order thinking: The threestory intellect. Theory Into Practice, 32(3)161-169.

[24] From Fogarty, R., and Stoehr, J. (1991). 1991. Integrating Curricula with Multiple Intelligences: Teams, Themes, and Threads. Skylight Publishing, Inc.

[25] Ghery Priscylio, Mulyadi, D.R. (2018). Needs of integrated science experiment student worksheet in junior high school to improve students science process skills. International Conference on Mathematics and Science Education (ICMScE)

[26] Gito Hadiprayitno, M.M. (2018). Pengembangan Media Pembelajaran Macromedia Flash Berorientasi Pembelajaran IPA Terpadu Tipe Connected. J. Pijar MIPA, VI(2).42-49.

[27] Hart, C. (2018.) Doing a Literature Review: Releasing the Research Imagination. SAGE Publication.

[28] Hasnawati .(2013). Sistem pembelajaran terpadu di sekolah. Marwah, 12(1). 1-13.

[29] Jr, R.V.B. (1999). Pat Solutions to Current Problems In Curriculum Integration: The Contributions of Harold Alberty. Journal of Curriculum and Supervision, 14(2) 156-170.

[30] Kemendikbud 2013. Bahan Ajar Pengelolaan Pembelajaran Tematik Terpadu.

[31] Kesipudin and Hikmawati . (2008). Model Pembelajaran Terpadu untuk Sains. J. Pijar MIPA, 3 (1)17-22.

[32] Khoirun Nisak, E.S. (2018). Pengembangan Perangkat Pembelajaran Ipa Terpadu Tipe
Connected Pada Materi Pokok Sistem Eksresi Untuk Kelas IX SMP. Jurnal Pendidikan Sains (Jps), 1(1).81-84.

[33] Kim, M. and Aktan, T. (2014). How to enlarge the scope of the curriculum integration of mathematics and science (CIMAS): A delphi study. Eurasia Journal of Mathematics, Science and Technology Education, 10(5).455-469.

[34] Kiray, S.A. (2012). A New Model For The Integration Of Science and Mathematics: The Balance Model. Energy Education Science and Technology Part B: Social and Educational Studies, 4(3).1181-1196.

[35] Koniawan Fajar Rahmanto, Mohammad Masykuri, W.S. (2015). Pengembangan Modul IPA Terpadu Berbasis Inkuiri Terbimbing Dengan TEma Keju Untuk Meningkatkan Keterampilan Proses Sains Dan Hasil Belajar Siswa SMP Kelas VII. Jurnal Inkuiri, 4(4)109-120.

[36] Kurt, K. and Pehlivan, M. (2013). Integrated Programs for Science and Mathematics: Review of Related Literature. International Journal of Education in Mathematics, Science, and Technology, 1(2) 116-121.

[37] Luminita Mihaela Draghicescu, Gabriel Gorghiu, Laura Monica Gorghiu, A.M.P. (2013). Pleading for an Integrated Curriculum. Journal of Science and Art, 1(22).89-95.

[38] Makhrus, M.\& and HadiPrayitno, G. (2012). Penerapan Perangkat Pembelajaran Fisika Berorientasi Pembelajaran IPA Terpadu Tipe Connected. Jurnal Pendidikan dan Pembelajaran, 19(2). 237-242.

[39] Mc Bee, R.H. (2016). Why teachers integrate. Educational Forum, 64(3). 254-260.

[40] Nailin Asfiah, Mosik, E.P. (2013). Pengembangan Modul IPA Terpadu Kontekstual Pada Tema Bunyi. Unnes Science Education Journal, 2(1).188-195.

[41] Nopy Widian Ningsih, Rudy Kustijono, I. (2013). Pengembangan Perangkat Pembelajaran IPA Terpadu Tipe Webbed Tema Tercemarkan Airku di Kelas VII SMP. Jurnal Pendidikan Sains e-Pensa, 1(1). 54-59.

[42] Nur Endah Nugraheni, Widha Sunarno, S. (2015). Pengembangan Modul IPA Terpadu Berbasis Inkuiri Terbimbing Dengan Tema Barbeque Kelas VII SMP Negeri 1 Talangmangu. Jurnal Inkuiri, 4(4). 43-53.

[43] Priscylio, G. et al. (2018). Needs of integrated science textbook for junior high school based on learning style ( descriptive research ). International Conference on Mathematics and Science Education (ICMScE)

[44] Rahayu, P. et al. (2012). Pengembangan Pembelajaran IPA Terpadu Dengan Menggunakan Model Pembelajaran Problem 
Base Melalui Lesson Study. Jurnal Pendidikan IPA Indonesia, 1(1).63-70.

[45] Rahmatika, R. (2016). Pengembangan Perangkat Pembelajaran IPA Dengan Pendekatan Scientific Pada Materi Sistem Eksresi Untuk Melatihkan Keterampilan Berpikir Kritis Siswa SMP. Jurnal Pena Sains, 3(2)

[46] Resty Rahmatika, Ismono, M.B. (2013). Perangkat pembelajaran IPA terpadu tipe Webbed Pada Tema Pengolahan Minyak Kelapa Untuk Siswa SMP Kelas VIII. Jurnal Pendidikan Sains e-Pensa, 1(2). 30-34.

[47] Septiana Indri Hapsari, Eko Hariyono, T.P. (2013). Pengembangan Lembar Kerja Kegiatan Siswa (LKS) IPA Terpadu Berbasis Guided Discovery Pada Tema Mitigasi Bencana Untuk Siswa Kelas VII SMP. Jurnal Pendidikan Sains (Jps) e-Pensa, 1(3). 28-33.

[48] Siti Mansurotun, Dyah Astriani, I.G.M.S. (2014). Pengembangan Perangkat Pembelajaran IPA Terpadu Tipe Webbed Berorientasi Inkuiri Terbimbing Tema Rainbow Cake Untuk Siswa SMP/ MTs Kelas VIII. Jurnal Pendidikan Sains e-Pensa, 2(1)111-116.

[49] Sukartiningsih, W. (2016). Validity Teaching Materials of Indonesian Education In Beginning Class of Elementary School Course Based Integrated Science and Social Studies. Journal of Ecucation, Teaching and Learning, 1(2). 82-88.

[50] Supriatin, A. (2008). Peningkatan Kemampuan Koneksi Matematis Melalui Pembelajaran Tematik. Edusains, 1 (2).

[51] Surahman Oki Wiyono, Y. (2013). Pengembangan Perangkat Pembelajaran IPA Terpadu Tipe Shared Pada Materi Molekul dan Perubahan Energi Dalam Metabolisme Tumbuhan Hijau Kelas VIII. Jurnal Pendidikan Sains (Jps) e-Pensa, 1(1).35-41. 